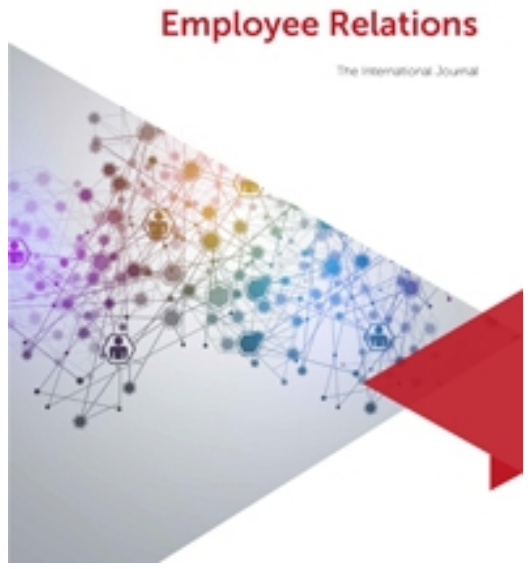

\title{
Workplace fiddles in the shipping industry
}

\begin{tabular}{|r|l|}
\hline Journal: & Employee Relations \\
\hline Manuscript ID & ER-07-2019-0294.R2 \\
\hline Manuscript Type: & Research Paper \\
\hline Keywords: & $\begin{array}{l}\text { Employee behaviour, Group behaviour, Occupational health and safety, } \\
\text { Seafarer }\end{array}$ \\
\hline \multicolumn{2}{|l}{} \\
\hline
\end{tabular}

SCHOLARONE ${ }^{\text {m }}$

Manuscripts 


\title{
Workplace fiddles in the shipping industry
}

\begin{abstract}
Purpose: The purpose of this paper is to examine the ways in which workers employ rule breaking, rule bending and deviations from management defined norms in the workplace and the impact this has on their occupational health and safety (OHS) experiences.
\end{abstract}

Design/Methodology/Approach: The paper uses qualitative semi-structured interviews conducted with thirty-seven seafarers working on board four vessels engaged in international trade. The data were recorded, transcribed and thematically analysed using NVivo software.

Findings: The findings indicate that seafarers utilised workplace fiddles - which included rule breaking, rule bending and deviating from management defined norms - in order to engender a workable system in which they could remain safe but also profitable to those who controlled their labour. Moreover, the findings suggest that shore-side management deflected the responsibility for rule violations by deferring many of the decisions regarding features of life on board - such as the scheduling of work hours - to the senior officers on board.

Originality/Value: The paper sheds light on where, in practice, responsibility for OHS lies in the international shipping industry, an industry in which workers experience relatively high rates of work-related fatalities, injuries and mental health conditions.

\section{Introduction}

Whilst the ways in which work is organised have changed considerably since the early 1900's, much of what is considered today as the norm stems from Taylorism, and consequently, work methods are both standardised and formalised.

Despite such standardised ways of working, research indicates that workers utilise their tacit knowledge and accumulated knowledge to circumvent workplace procedures in order to maintain control over the environment in which they work. In his ethnographic study of deeplevel mining, Phakathi (2017) revealed numerous ways in which workers manipulated formalised work systems, such as frontline miners utilising creative informal practices to resolve bottlenecks in the extraction of mineral-bearing rock.

Workplace behaviour in which workers manipulate formalised work systems are referred to in the literature as workplace fiddles. Whist several definitions of workplace fiddles exist, the term is used here to denote behaviour that involves workers utilising their knowledge and experience to break or bend workplace rules (Webb and Palmer 1998). This behaviour may include what Sewell and Wilkinson (1992) term 'divergences from management defined norms'.

In their dimensions of workplace fiddles model Webb and Palmer (1998) argue that workplace fiddles can be viewed along two dimensions. First, they can be categorised according to whether they are pursued by an individual or a group of workers acting collectively. "Collective action denotes that the beneficiary of the fiddle is dependent upon the active complicity of another worker" (Webb and Palmer 1998, p.616). Second, they can be categorised according to either evading surveillance or making time. Evading surveillance is considered to be action which is essentially defensive, with the aim being to avoid detection by management. Making time, on the other hand, is defined as action which enables workers to gain some measure of control over their immediate work environment.

Several studies suggest that workplace fiddles can - in some circumstances - have positive implications for both employers and employees. Richards (2008) calls such behaviour 
functional misbehaviour which they define as behaviour that does not comply with official instructions but leads to positive outcomes for the employer organisation. Similarly, in his study of the British Army, Kirke (2010) states that some behaviour which bends or breaks rules can make the working lives of those concerned easier without compromising the reputation or effectiveness of the employer. Examples include hiding surplus equipment during inspections so as not to have the spare equipment - which was anticipated to prove useful at a later date - removed from the troop and exaggerating the quantity of equipment destroyed in an incident so as to gain extra items (Kirke 2010).

Deery et al. (2010) also suggested that work groups are sometimes able to create norms which shield workers from the adverse effects of stressful job demands. In their study of call centre workers, emotional exhaustion and work intensification were mitigated through a shared cultured of absenteeism whereby a permissive attitude of absence taking was prevalent.

Conversely, there is a body of research which indicates that work methods which deviate from formal safety rules and procedures can have serious repercussions for occupational health and safety (OHS). Hopkins (1984) found that both management and miners tolerated concentrations of methane gas which were substantially higher than formally permitted and this informal tolerance was cited as a factor in the deaths of fourteen miners in 1979 when the Appin Colliery experienced an explosion of methane gas. Similarly, Nichols (1997) discovered that one of the key causes of occupational injuries in the manufacturing and mining companies which he studied was the deviation from formal safety rules. When production blockages - such as breakdowns in machinery - occurred, workers bypassed formal safety rules in order to restore production. Thus, the workers broke safety rules in order to cope with management pressure to keep levels production up (Nichols 1997).

Taking these findings as its basis, and by utilising Webb and Palmer's (1998) dimensions of worker fiddles categorisations, this study explores workplace fiddles in the international shipping industry - an industry in which OHS is a particular concern. Whilst it is difficult to obtain accurate figures, those who work at sea have higher rates of fatalities (Roberts et al. 2014) and occupational injuries (Hansen et al. 2002), as well as relatively high rates of depression, anxiety and suicidal ideation (Lefkowitz et al. 2019) than many workers in shorebased occupations. These issues make the international shipping industry a particularly interesting industry in which to study workers' use of workplace fiddles and the impact this had on their OHS experiences.

\section{Structure of the international shipping industry}

There are several factors related to the structure of the international shipping industry which are likely to influence the use of workplace fiddles by those who work at sea. In recent decades this structure has changed considerably and one feature of this has been the rise in ship owners use of third-party ship managers. In 2018, third-party ship managers were estimated to have nearly $13 \%$ of the global shipping fleet under their management, despite the first instance of third-party ship management occurring only 43 years earlier (Lloyds List 2018). These managers offer a range of services including technical management, crewing management and even full commercial management.

Another key change has been the enabling of ship-owners to shift the registry of their ships from their country of domicile to other countries with comparatively relaxed regulatory conditions. These relaxed regulatory requirements have had an important impact on the ways in which work and employment in the industry are organised. First, ship-owners have been encouraged to source seafarers from new (and cheaper) labour supply countries (Alderton et 
al. 2004). Consequently, multi-national crews - in which seafarers of three of more nationalities work alongside one another - are now the norm (Wu and Winchester 2005).

Second, ship-owners have moved to flags with lower safe manning requirements and this has resulted in downsizing so that only the bare minimum number of individuals is on board and consequently there is a lack of colleagues to assist with additional work tasks or to cover extra working hours. Literature indicates that downsizing has had a negative impact on seafarers' fatigue, which in turn adversely impacts on OHS outcomes (see, for example, Pollard et al. 1990).

Third, in seeking a cost-efficient way of operating their businesses, ship-owners have replaced permanent labour with seafarers employed on single-voyage contracts, often recruited via third-party crewing agencies. Employment insecurity is known to pose issues for OHS in several ways. For example, precariously employed workers have been seen to be more likely to take workplace risks due to fears of dismissal and may lack knowledge regarding their OHS rights (Underhill and Quinlan 2011). Such workers may also lack knowledge regarding workplace OHS procedures due to lack of training (Underhill and Quinlan 2011).

In many cases seafarers are employed via third-party crewing companies and the shipping company has no direct relationship with those on board the vessels they own. Consequently, the seafarers rarely have any relationship with shore-side management (who are physically removed) - an issue which Sampson et al. (2019) have revealed to be of importance when considering trust between management and the workforce. A lack of trust between the seafaring labour force and shore-side management is known to have a number of implications for OHS, including the under-reporting of injuries by seafarers (Bhattacharya 2012b).

The current employment methods also impact on the familiarity between seafarers on board as fluid crews, made up of seafarers who do not return to the same vessel - or even the same shipping company - for subsequent tours of duty, are widespread. Additionally, crew changes tend to be staggered, and consequently seafarers may become familiar with their supervisors and colleagues on board only for some of their colleagues to leave the vessel at the end of their tours of duty and be replaced by new unfamiliar seafarers. These are particularly important structural issues when considering OHS in the shipping industry.

\section{OHS features of the international shipping industry}

Seafaring is a relatively dangerous occupation with seafarers' seen to be around 21 times more likely to experience a fatal occupational accident than other workers in the British workforce (Roberts et al. 2014). Whilst figures vary between countries and fleets, fatality rates for seafarers are higher than for workers in most land-based occupations around the world (Jaremin 2005). Moreover, rates of non-fatal occupational injuries among the seafaring workforce are of concern (see, for example, Hansen et al. 2002). A recent study has also revealed that seafarers have higher rates of depression that workers in other occupations (Lefkowitz et al. 2019). The OHS of seafarers is therefore a clear concern. However, regulating OHS in the international shipping industry is a substantial challenge. By the very nature of the industry ships spend most of their time at sea, physically removed from regulatory authorities. The enforcement of regulations in the international shipping industry primarily falls on the flag state - that is the state under which each ship is registered. Shipping registers fall into three broad categories: national shipping registers, secondary shipping registers and open registers. National shipping registers are registers for ships whose owners have links to the country of registry such as a place of business in the country, and historically these registers have tended to be in the traditional maritime countries. Since the 
1940's ship owners have moved their registration from national registers to open registers in substantial numbers (DeSombre 2008). Open registers are states which have very few restrictions regarding the registration of ships from any nation. These registers appeal to ship owners as they predominantly offer low taxes, registration fees and inspection fees as well as lax standards in terms of regulatory oversight (DeSombre 2008). In an attempt to increase ship registrations, a number of traditional maritime countries have set up 'secondary registers' alongside national registers. These secondary registers offer greater beneficial environments for ship owners in comparison to the national register (Alderton and Winchester 2003). These secondary registers represent a middle ground between the weak regulatory environment of open registers and the stringent environment of national registers.

Within the international shipping industry, a regulatory framework to govern is provided by the International Maritime Organisation (IMO) and there are several important regulatory instruments of global governance including the International Convention on Standards of Training, Certification and Watch Keeping for Seafarers (1978) (STCW) and the International Convention for the Safety of Life at Sea (1974) (SOLAS) - which contains the International Safety Management (ISM) Code. The introduction of the ISM code in 1998 brought regulated self-regulation to the international shipping industry. In complying with the ISM Code, shipping companies are expected to produce their own specific policies and procedures, commonly known as a Safety Management System (SMS). The policies and procedures within the SMS dictate many of the aspects of life on board including each individual's responsibilities and duties on board, including their responsibilities whilst mooring the vessel and whilst the vessel is in port. The SMS also details things such as oncall procedures for unmanned machinery spaces and the requirement for Cadets to receive time off from work on a weekly basis to undertake academic studying. Whilst the introduction of the ISM Code has resulted in a systematic approach to OHS management at sea, there is substantial criticism of the code. Bhattacharya $(2012 b)$ revealed that the Code requires a participatory approach, something which is unlikely owing to the organisational context and employment relations which currently exist in the international shipping industry.

In addition to the IMO, the International Labour Organisation (ILO) has played an important role in regulating the international shipping industry. In particular, the ILO's (2006) Maritime Labour Convention (MLC) sets out the rights of the world's seafaring labour force to decent conditions of work. The MLC regulates several important aspects of work on board ships including seafarers' hours of rest. It also requires the flag state to develop a table of shipboard working arrangements for each ship. The table of shipboard working arrangements must include all of the occupational positions on board and it must be prominently displayed on board. It enables all seafarers on board a vessel to be aware of their daily working routine whilst the ship is both at sea and in port. A copy of the table of shipboard working arrangements for one of the product/chemical tankers on which interviews were conducted for this study can be seen in appendix I.

In addition to the work carried out by both the IMO and ILO, trade unions have played an important role in the development of labour regulation (Walters and Bailey 2013). Across all industries the importance of trade unions in the management of OHS is widely acknowledged. In a systematic review of OHS management literature, Bohle and Quinlan (2000) pointed to the need for effective worker representation in OHS management, whereby the workforce needed to be organised and able to present their view in a representative manner. Similarly, Walters (1996) also indicates that a strong trade union presence is necessary for effective representative participation. At a shipboard level, however, trade 
union presence is in most cases non-existent due to the nature of the workplace and the precariousness of the labour (Walters and Bailey 2013).

This paper, therefore, examines the reality of breaking rules, bending rules and deviating from management defined norms for workers in a challenging industry. In doing so such behaviours are presented as a double-edged sword depending on both their purpose and application in the absence of a strong trade union presence.

\section{Method}

In order to explore seafarers' experiences of workplace fiddles, this research took a qualitative approach. The research was conducted in accordance with the ethical standards required by Cardiff University. Qualitative semi-structured interviews were conducted with thirty-seven seafarers working on board four vessels. This research method was chosen as it allowed a structure which enabled a degree of comparability whilst also allowing respondents to answer on their own terms (Bryman 2016).

The researcher joined each of the four ships immediately after they had berthed in various UK ports and remained on board until the vessel commenced departure checks (approximately one hour before sailing). All of the interviews were conducted in private rooms on board.

The ships included an offshore support vessel and three chemical/product tankers. The size of the crew varied between ten and twenty-three seafarers and whilst literature (see, for example, Winchester et al. 2006) indicates crew sizes vary in relation to ship size and type, the crew sizes of these vessels were generally representative of the current state of the industry as a whole in which the average crew size across ship types/sizes was found to be twenty-three (Deloitte 2011).

Each of the ships had three or more nationalities of seafarers on board and would therefore be considered as multi-national crewed vessels. Those interviewed were British, Dutch, Filipino, Norwegian, Polish, Romanian, Russian and Swedish.

The ages of the participants ranged from 20 to 62, and the average age was 39 . Thirty-six of the thirty-seven participants were male, however, the gender imbalance of the participants is representative of the industry in which female seafarers are estimated to account for $2 \%$ of the workforce (ITF 2019).

On board a ship seafarers are generally employed in either the deck, engine or hotel department. Within both the deck and engine departments there are senior officers, junior officers, trainee officers - known as Cadets - and ratings. Ratings are seafarers who are employed in roles requiring lower levels of professional seafaring qualifications (Glen 2008). Seafarers in the deck department navigate the vessel and in port they load and discharge cargo and maintain a security watch. Those in the engine department undertake the monitoring and maintenance of the machinery and equipment on board. Finally, seafarers in the hotel department tend to be ratings and these individuals take care of the domestic requirements such as cooking and cleaning.

Of the thirty-seven seafarers who participated in this study, ten were senior officers, eleven were junior officers, twelve were ratings and four were cadets. The participants were from each of the occupational departments on board, with twenty-two from the deck department, ten from the engine department and five from the hotel department. 
Each of the four ships sailed world-wide, however, at the time of study the offshore support vessel was predominantly involved in work in an oil field in the North Sea. Two of the chemical tankers were principally short-sea trading around North-West Europe and the third was trading deep-sea in the long-haul trade. The flag state under which each was registered varied. However, the classification of the four flag states was either white or grey. ${ }^{i}$ This would suggest that all four vessels visited were from the 'better end' of the international shipping industry.

English was the working language on board all four vessels and all the interviews were conducted in English, digitally recorded and subsequently transcribed verbatim.

Transcriptions were coded using NVivo. Numerous codes were generated from the data, and these were then grouped based on areas of commonality, giving rise to the themes explored below.

\section{Findings}

The following sections describe the workplace fiddles our participants talked about, using the categories included in Webb and Palmer's (1998) dimensions of worker fiddles model.

\section{Making time: Individual action}

Seafarers developed individual ways of organising their own working practices in order to exert some measure of control over their working environment. In organising their working schedules these seafarers diverged from the shore-side defined norms. One Captain, for example, stated:

"If I want to go ashore for example I can plan my administration work and maybe to do it the next day" Captain.

In accordance with their contract of employment and the table of shipboard working arrangements as detailed in the MLC (2006), the Captain would be expected to work every day whilst on board. Nevertheless, such rearranging is likely to positively impact on the Captain's well-being as prior studies (see, for example, Bauer 2007) indicate shore leave to be a significant factor in improving the well-being experiences of seafarers.

Similarly, some seafarers reported being able to adjust their work schedule so as to work when weather conditions were more favourable. One junior officer explained how he adjusted his working schedule to avoid working on the exposed weather decks at particularly hot times of the day:

"I was on the 8-12 watch then and if you've got safety stuff to do, you know 2 hours during the day after lunch and of course they can call you for mooring as well....... Sometimes when we were like at anchor and it was really hot cos we were stuck off $U A E$, so after dinner in the evening I'd go and make a round on deck or whatever instead of after lunch" Junior Officer.

The table of shipboard working arrangements states that the watch keeping officer on the 0800-1200 watch should carry out non-watch keeping duties after lunch at 1300-1500 and thus the junior officer deviated from these pre-determined hours of work. 


\section{Making time: Collective Actions}

Seafarers also utilised collective fiddles in order to make time and some reported divergences from shipping company defined norms in relation to work scheduling. For example, despite the SMS detailing the company policy regarding the on-call procedure for unmanned machinery spaces and the rotation for which individuals were to be on-call, some seafarers reported senior officers swapping with seafarers who, in accordance with the SMS, should have be on-call:

"If you have bad luck when you join the ship you can be on duty but unofficially we do this that this one who's joining he's never on duty so let's say the Second [Engineer] will take his first night yeah, or let's say on this night I was not on duty because it was the duty of the Second Engineer but we had a crew change and they just arrived in the evening so I said, well this has become normal practice, take a rest, I will take the duty until 0800" Senior Officer.

Similarly, one senior officer detailed how the Captain would adjust his own working schedule to make the schedule of the senior officer, on his first day on board, less of a burden.

"The Captain used to plan that quite good so sometimes if I join the ship direct then I can sleep to the morning or something so he will arrange that, so far he have handled it really good, if I have been awake from early morning because of the flight and I arrive in the evening then more or less he would have started up everything and I can rest and start in the morning" Senior Officer.

In accordance with the table of shipboard workings the Senior Officer should have been working between the hours of 1600 and 2000 - irrespective of how long prior to this time they had arrived on board or the duration of their travel to the vessel.

One head of department revealed that he utilised a democratic approach to work scheduling whereby a majority decision from the team members determined which hours the entire team would work - as opposed to following the pre-determined hours of work as shown in the table of shipboard working arrangements. He stated:

"[A] 7 o'clock start in the morning is quite early but the lads want to do that in order to finish at 4 if possible so I've had people start at 8 and finish at 5 I'm flexible either way, whatever they want to do" Senior Officer.

Many of these divergences from the norms defined by the shipping company appeared to be seafarers' responses to situations which they perceived were not adequately addressed by either regulations or company procedures. For example, there are no regulations which prohibit seafarers from travelling a long distance to join the vessel and immediately commencing work on board. In fact, in a study regarding fatigue Wadsworth et al. (2008) revealed that $66 \%$ of participants in a questionnaire study stated that they did not have the opportunity to sleep between travelling to a ship and beginning work on board. Of this group $47 \%$ had travelled more than 6 hours and $19 \%$ for 12 or more hours. Consequently seafarers diverging from the management defined norm in a manner whereby new joining seafarers were not immediately on call or their shifts were covered whilst they rested - two examples which were presented above - is prudent behaviour which is likely to have positive implications for not only the OHS of the new-joining seafarer but also for the safety of the vessel and its crew as a whole. 
Divergences from management defined norms were also seen to include the allocating of work tasks and some of those interviewed revealed that they arranged their work tasks in a collective manner which resulted in colleagues who were more familiar carrying out the tasks at times when it was perceived to be particularly risky. For example, one rating stated:

"We've just done a lot of tank cleaning on here before going to dry dock and line washing and educting and that some of it had to be done during night time like me and [seafarers name] burst it between the 2 of us, we went sixes and me and [seafarers name] agreed, I had a bit more experience especially when it comes to draining the lines and that because at the time we had one new lad not too clued up on that and the last thing you want to be doing is trying to get him to do something so what we were doing during the daytime was just working like normal two of us together and when it got dark he [new seafarer] went to the bridge and I just stayed on, done what needed to be done" Rating.

The SMS details the roles and responsibilities for each individual on board depending on both their rank and work shift. In this example the rating who remained on deck should have, in accordance with company procedures, been undertaking lookout duties on the bridge during the hours of darkness. Instead the rating who was less familiar with the vessel carried out the lookout duties.

Research from shore-based industries has shown that workers experience an increased risk of occupational injury when they are new on the job (Breslin and Smith 2006). Thus, seafarers arranging their work tasks such that those who are more experienced and familiar with particular tasks carry them out is likely to have positive implications for OHS. Moreover, as many of the work tasks undertaken on board are safety critical, arranging them in this manner is likely to be prudent for the safety of the vessel.

In previous studies (see for example Parry 2003) workers in occupations such as mining were seen to form tight-knit communities and relied on their colleagues in relation to their own colleagues. Such colleagues formed bonds over extended periods of time and often shared very close cultural identities, having attended the same schools and grown up alongside one another in the same villages. It is particularly noteworthy therefore that the seafarers in this study utilised collective actions to gain some control over their own immediate working environment despite unfamiliarity with their colleagues, whom they would likely work with only for a few weeks or months.

During the analysis it emerged that the use of collective action for making time did not always positively impact on the OHS of each team member. One junior officer revealed that he had experienced ill treatment as a consequence of others in the work team re-organising their own work. In explaining his experiences on board a previous vessel, the junior officer stated:

"When I was with [company name] I was doing sixes" all the time cos we had this lazy Chief Officer” Junior Officer.

The comment indicates that instead of the usual working routine of 4 hours on/ 8 hours off the Chief Officer (a senior officer) had instructed him to work 6 hours on/6 hours off - thereby working the hours the Chief Officer should have been working. 
In complying with these collective actions such individuals were not co-operating for the good of the group or because they agreed with the work scheduling arrangements, they simply had no choice but to do as instructed by a more senior officer who was abusing the power they held. Thus, some individuals held the power to organise things, whilst others on board did not.

Moreover, the use of informally arranged collective actions which deviated from the shipping companies' polices resulted in some seafarers' work schedules changing when their colleagues on board departed from the vessel and new colleagues joined. For example, on board one of the vessels the company policy as detailed in the SMS stated that Cadets (trainee officers) were to be given 15 hours per week for academic study and if the vessel was at sea this time should be given as a half-day on a Saturday and a full day on a Sunday. During the data collection one Cadet, however, was not aware of which days he would be working as the previous Chief Officer - who had informally decided which days the Cadet worked, rather than following the company's policies - had completed his tour of duty and departed the vessel that day and had been replaced by a new joining Chief Officer. The Cadet explained:

"It depends on the Chief Mate or whatever so with the last Chief Mate we worked all day Saturday and got a half day or usually a full day off on a Sunday but obviously, this Chief Officer is new and I think its half day Saturday full day Sunday but it might be work, but usually I get at least one day [off]" Cadet.

Seafarers may experience changes in the work team fairly regularly. In a situation whereby a new joining seafarer changes the informal work practices of their predecessor it may be that those subjected to the change perceive being ill-treated - particularly if such changes result in additional work, a situation that is feasible given the statement made by one head of a department:

"Saturday afternoons and Sunday afternoons we are usually cheating the working time. We say that we work but actually we are relaxing” Senior Officer.

In accordance with the Table of Shipboard Working Arrangements the Senior Officer (and the rest of the team) should have been working on both a Saturday and a Sunday. Thus, if the new joining senior officer was unwilling to diverge from the company's policies and also allow those in his department to rest on Saturday and Sunday afternoons, discontent among the team is likely. A reduction in the amount of rest a seafarer experiences is likely to impact on fatigue and will thus have adverse consequences for OHS outcomes.

\section{Individual action: Evading Surveillance}

Seafarers developed individual methods of evading detection of contravention of company policies and regulations. In some cases, policies and regulations which were contravened were international regulations. By fabricating legally required records seafarers were able to ensure that violations were not noticed by shore-side inspectors. For example, one head of an engineering department stated:

"When we are playing, gambling with the rest hours to make sure we don't get red for a stupid half an hour somewhere. I'll have a look, maybe I took 2 hours' lunch instead of 1 hour, little bit forgery, not big forgery, just small" Senior Officer. 
The MLC (2006) states that seafarers' records of hours of rest must be made available for inspection by both flag state control inspectors and port state control inspectors. In addition commercial hirers of ships, particularly in the oil sector may also conduct inspections of vessels and may request to see various records, including records detailing seafarers' hours of rest on the vessel.

In detailing how he tried to evade surveillance from shore-side inspectors, the senior officer went on to say:

"Somethings you cannot move [rest hours] too much because arrival and departure is always noted the times officially in the logbooks and everything so them I cannot move and also when we're taking bunkering I cannot move that because those are official times logged there. That's the first thing they [inspectors] check, how many engineers were awake" Senior Officer.

A further area in which seafarers evaded surveillance was when injuries occurred. Seafarers were seen to be reluctant to report injuries, with one Captain stating:

"If I don't report it I think it's not so serious. Let's say that I go on a ladder here and I miss the steps and I fall down and I hit my arm but I feel that ah it's just nothing. To report something it's a lot of paperwork all the time, I don't want to have so much paperwork so any minor of myself if not so necessary. If anybody else I have to report it, if they come to me I report but there can be the situation also that they keep it for themselves" Captain.

The Captain was keen to avoid the time-consuming task of completing an injury report, thus saving time, as well as avoiding drawing shore-side management's attention to events on board.

Similarly, a junior office reflected on an injury he had experienced earlier in his career that he had not reported:

"I was going to get bollocked for it mainly, well back when I was cadet, I wouldn't care as much now obviously....I was coming down a ladder and I swung on the thing and I slipped off and landed on top of my foot and I didn't report it and my foot swelled up quite badly but I didn't report it because [captains name] was the old man and it was an Indian Second Mate so he'd make a big thing about it, write a report, I couldn't really be bothered with that so I never told anyone" Junior Officer.

Like the Captain, the Junior Officer did not want to draw shore-side management's attention to the fact that he had experienced an injury.

\section{Collective action: Evading Surveillance}

Seafarers also utilised collective actions in order to evade surveillance whereby noncompliance of regulations and company policies occurred. For example, two seafarers acted collectively to sign a checklist to state that a familiarisation tour for a new joining seafarer something which is required both by regulation (SOLAS and STCW) and company policy had taken place, when in fact it had not. The officer who had just joined the vessel explained: 
Owing to the intensive workloads of seafarers whilst in port and the insufficient duration of handover periods seafarers did not have the time to conduct familiarisation tours for new joining seafarers.

Whilst in the above example the seafarers appeared to co-operate in order to evade surveillance, it became apparent that such co-operation was not always immediately forthcoming and some individuals 'persuaded' others to co-operate in such fiddles. One junior officer described an event in which he had recorded a non-compliance with rest hour legislation. A short time later he discovered that his records had been altered by the senior officers on board in a manner which resulted in the non-compliance not being recorded. The seafarer explained the incident as follows:

"Everybody was breaking hours of work then and later on you know you go and look at your hours of work and you're still in compliance somehow even though you filled it in yourself and you were in noncompliance. The Chief had been tampering with it" Junior Officer

Upon querying the changes, the junior officer was pressured by the Chief Officer - an individual who was higher in the occupational hierarchy - to go along with the falsification of the rest hour records. The junior officer stated:

"I went to him [the Chief Officer] and said look what's going on, so he says, I'm you know, I'm telling you" Junior Officer.

Requirements for seafarers' rest hours are determined by STCW and the requirements for seafarers to undertake suitable familiarisation are stated in the ISM Code (and STCW). Regulations for rest hours directly impact on seafarers' fatigue, an issue which is known to relate to well-being, as well as safety.

\section{Discussion and conclusions}

The results of this study add to the body of literature which examines frontline workers' experiences of workplace fiddles and the ways in which these fiddles can both serve and inhibit workers. Moreover, in considering fiddles this paper sheds light on where, in practice, the responsibility for OHS lies.

Whilst it was clearly evident in our data that fiddles could be individual or collective, the dimension of making time/evading surveillance was confounded - suggesting that Webb and Palmer's (1998) workplace dimensions model, which considers the categorisation of fiddles as two dimensional, does not tell the whole story. Rather, the findings of this study indicate that, in many instances, evading surveillance was necessary in order to make time. Simply 
put, there was not enough slack in the system to allow seafarers the time to be compliant with all requirements, a situation which inevitably led them taking action to avoid the attention of shore-side management.

Issues such as falsifying familiarisation training records ensure seafarers appeared compliant and so avoided any sanctions. However, such actions also indicate that seafarers make time because there is not enough time available when a new seafarer joins a vessel to allow for familiarisation to be done without compromising the other work happening on board (see, for example, Vidan et al.'s 2015 study regarding the familiarisation of Croatian and Montenegrin seafarers).

Similarly, by not reporting injuries seafarers evaded surveillance but they also avoided the time-consuming task of completing the associated paperwork, thus buying themselves time to get the job done in a situation where they otherwise could not. The under-reporting of injuries among those who work at sea is a well-known issue. In one study Psarros et al. (2010) revealed that around $30 \%$ of injuries were reported. Consequently, the occupational injuries which are reported in the seafaring industry are likely to be the tip of the iceberg. Research (see, for example, Bhattacharya 2012a) indicates that many injuries are not reported owing to seafarers' fears of drawing attention to themselves - a finding mirrored in this study.

Hours of rest records were wrongly filled in and seafarers appeared to be - on paper - rule abiding individuals even when this was not the case. These findings corroborate other studies in which seafarers were revealed to regularly falsify rest hours records and under-report working hours (Bloor 2003; Allen et al. 2006), thus supporting the argument that shore-side's impressions of seafarers' experiences may not be accurate. In the same vein as falsifying training records, seafarers normalised the breaking of rest hour requirements simply because their workloads did not allow them to do otherwise. Thus, regulations and management defined norms were not fit for purpose and seafarers were violating rules to engender a workable system. These findings are in keeping with Nichols and Armstrong (1973) who showed that workers in British factories normalised their approach to breaking safety rules such as by bypassing formal safety rules in order to restore production when production blockages occurred - to ensure that they were able to work in a way which remained profitable to their employers. Similar findings also emerged in Kurt et al's (2015) study of shipboard standard operating procedures which revealed that procedures do not always reflect operational reality and are, in some cases, impossible to follow.

The reasons why seafarers were keen to present themselves as rule-abiding to shore-side management even when this was not the case are not difficult to understand. Seafarers are predominantly employed on temporary contracts (Ellis et al. 2012) and for many these contracts are difficult to obtain due to a surplus of individuals seeking employment at sea. Moreover, in many countries the salary earned by seafarers is significantly higher than the average salary ashore and consequently seafaring is viewed as a lucrative occupation. Worryingly, seafarers are also aware of the ease with which they can be blacklisted and denied future employment (Sampson 2013). Thus, many seafarers are reluctant to say or do anything which may jeopardise their future employment at sea. Furthermore, with the increasingly weak position of organised labour - owing to the emergence of multinational crews, drawn from a global labour market with little, if any, common trade union identity seafarers are unable to rely on the support and protection typically provided by trade unions (Walters and Bailey 2013).

Abuses of power and negative treatment inflicted on some seafarers by their colleagues such as the example presented above in which a junior officer was working additional hours 
due to the demands of the Chief Officer - are also likely to go unreported for the same reasons. Examples of abuses of power by senior officers at sea are not unique to this study. In her ethnographic work Sampson (2013) presented a similar example of a Captain she described as a bully, who overtly and unpleasantly exercised his power to the detriment of the other seafarers on board. Away from the oversight of shore-side management it is easier for workers to adopt such fiddles and owing to their weak position trade unions are unable to act as a buffer from rogue officers exploiting their position of power thus resulting in an absence of checks and balances. Moreover, the reluctance of seafarers to do anything which could jeopardise their future employment indicates a lack of trust between seafarers and shore-side management, something which is highlighted in recent work by Sampson et al. (2019). A lack of trust is unsurprising given the current employment practices in the industry which have resulted in seafarers experiencing no meaningful relationship with those who operate the ships on which they work.

Given the nature of many of the workplace fiddles, it appeared that shore-side management were only too willing for many of the fiddles undertaken by seafarers to remain invisible to them. In accepting the falsified documents - such as hours of rest records - at face value shore-side management were able to present themselves as committed, but at the same able to avoid any rectifications - such as increasing the number of seafarers on board - which would negatively impact on their profit. This, of course, mirrors research from other industries which indicates that management are willing to turn a blind eye to workplace fiddles - even when such fiddles involve breaking safety rules - if doing so enables production targets to be met (see, for example, Nichols 1997).

Responsibilisation - in which workers are assigned responsibility for their own occupational safety and are considered to be accountable and judged as such - has redefined workers as both victims and offenders of OHS violations (Gray 2009). Taken together the findings presented above suggest that those who work at sea are both offenders and potential victims of rule violations. In producing false records seafarers were offenders whilst at the same time having little choice but to undertake workplace practices which left them at risk of adverse OHS experiences, thus making them victims.

Shore-side management further deflected the responsibility for rule violations by deferring many of the decisions regarding features of life on board to the senior officers on board. Thus, shore-side management was able to distance itself should any rule violations be identified by regulatory bodies. Such deferring again moves the responsibility of OHS violations and transgressions to the workers - which again, suggests that, in practice, much of the responsibility for OHS in the international shipping industry lies with those individuals who work on board.

Seafaring has always been and remains a dangerous occupation. The findings presented here indicate that, despite regulation and on board safety management arrangements, even seafarers at the better end of the industry find ways, individually and collectively, to bend and break rules. For the most part, their aim in doing so is to reduce the risk to their own and their colleagues' safety and, in particular, health and wellbeing, that result from the ways in which their work is (meant to be) organised. In essence, seafarers in this study were finding ways of 'buying time' to gain control over their work environment and mitigate stress, fatigue, work intensity and so on, and shore-side management turned a blind eye not only to them doing so, but in particular to the factors that drove them to do so. This reflects findings from other sectors suggesting a gap between the understandings of management and workforces of the experience of workplace health and safety as a result of a narrow corporate focus on just the safety part of OHS (see, for example, Walters and Wadsworth 2020). 
This study has identified concerns surrounding the need for workers to violate rules and management defined norms in order to bring about a workable system. Given that our data are drawn from the 'better end' of the industry, these problems are likely magnified in the rest of the sector. As indicated above, within a highly regulated global industry, there is much that shipping companies and policy makers could do to address these concerns and so improve seafarers' working conditions.

\section{Funding}

This research was supported by a Seafarers International Research Centre-Nippon Foundation Fellowship.

\section{Acknowledgments}

We are grateful to the four ships that hosted the research and the seafarers who shared their experiences with us. The authors also wish to thank Professor David Walters for his guidance.

\section{References}

Alderton, T., Bloor, M., Kahveci, E., Lane, T., Sampson, H., Zhao, M., Thomas, M., Winchester, N. and Wu, B., 2004. The global seafarer: Living and working conditions in a globalized industry. International Labour Organization.

Allen, P., Wadsworth, E., \& Smith, A. P. 2006. The relationship between recorded hours of work and fatigue in seafarers. Contemporary Ergonomics, pp. 546-548.

Bauer, P.J., 2007. The Maritime Labour Convention: An Adequate Guarantee of Seafarer Rights, and Impediment to True Reforms Development. Chi. J. Int'1 L. 8, pp. 643-660.

Bergantino, A. and Marlow, P., 1998. Factors influencing the choice of flag: empirical evidence. Maritime Policy and Management, 25(2), pp.157-174.

Bhattacharya, S. 2012a. Sociological factors influencing the practice of incident reporting: the case of the shipping industry. Employee Relations, pp. 4-21.

Bhattacharya, S., 2012b. The effectiveness of the ISM Code: A qualitative enquiry. Marine Policy, 36(2), pp.528-535.

Bloor, M. 2003. Problems of global governance: port-state control and ILO conventions. Seafarers International Research Centre (SIRC), Cardiff University.

Bohle, P. and Quinlan, M., 2000. Managing occupational health and safety: A multidisciplinary approach. Macmillan Education AU.

Breslin, F. C., \& Smith, P. 2006. Trial by fire: a multivariate examination of the relation between job tenure and work injuries. Occupational and environmental medicine, 63(1), pp. 27-32.

Bryman, A., 2016. Social research methods. Oxford university press. 
Deery, S.J., Iverson, R.D. and Walsh, J.T., 2010. Coping strategies in call centres: Work intensity and the role of co-workers and supervisors. British Journal of Industrial Relations, 48(1), pp.181-200.

Deloitte. 2011. Challenges to the industry: Securing skilled crews in today's marketplace [Online]. Available at:

https://www2.deloitte.com/content/dam/Deloitte/global/Documents/dttl-er-challengeindustry08072013.pdf

DeSombre, E.R., 2008. Globalization, competition, and convergence: shipping and the race to the middle. Global Governance, pp.179-198.

Ellis, N., Sampson, H., Acejo, I., Tang, L., Turgo, N., \& Zhao, Z. 2012. Seafarer accommodation on contemporary cargo ships. Seafarers International Research Centre (SIRC), Cardiff University.

Gray, G. C. 2009. The responsibilization strategy of health and safety: Neo-liberalism and the reconfiguration of individual responsibility for risk. The British Journal of

Criminology, 49(3), 326-342.

Hansen, H. L., Nielsen, D., \& Frydenberg, M. 2002. Occupational accidents aboard merchant ships. Occupational and environmental medicine, 59(2), pp. 85-91.

Hopkins, A., 1984. Blood money? The effect of bonus pay on safety in coal mines. The Australian and New Zealand Journal of Sociology, 20(1), pp.23-46.

ITF. 2019. Women seafarers [Online]. Available at: https://www.itfseafarers.org/ITI-womenseafarers.cfm

Jaremin, B., 2005. Work-site casualties and environmental risk assessment on board Polish vessels. International maritime health, 56(1-4), pp.17-27.

Kirke, C., 2010. Orders is orders... aren't they? Rule bending and rule breaking in the British Army. Ethnography, 11(3), pp.359-380.

Kurt, R. E., Arslan, V., Turan, O., de Wolff, L., Wood, B., Arslan, O., Papadakis, G. (2015). SEAHORSE project: Dealing with maritime workarounds and developing smarter procedures. In L. Podofillini, B. Sudret, B. Stojadinović, E. Zio, \& W. Kröger (Eds.), Safety and Reliability of Complex Engineered Systems - Proceedings of the 25th European Safety and Reliability Conference, ESREL 2015 (pp. 3811-3818). Abingdon.

Lefkowitz, R.Y., Slade, M.D. and Redlich, C.A., 2019. Rates and occupational characteristics of international seafarers with mental illness. Occupational medicine, 69(4), pp.279-282. Lloyds List. 2018. The future of ship management [online]. Available at: https://loydslist.maritimeintelligence.informa.com/LL1123762/The-future-ofshipmanagement

Nichols, T., 1997. The sociology of industrial injury. Mansell. 
Nichols, T. and Armstrong, P.J., 1973. Safety or Profit: Industrial Accidents and the conventional wisdom. The Falling Wall Press.

Paris MOU. 2017. White, grey and black list [Online]. Available at: https://www.parismou.org/detentions-banning/white-grey-and-black-list

Parry, J., 2003. The changing meaning of work: restructuring in the former coalmining communities of the South Wales Valleys. Work, Employment and Society, 17(2), pp.227-246.

Phakathi, S. T. 2017. Production, safety and teamwork in a deep-level mining workplace: Perspectives from the rock-face. Emerald Publishing Limited.

Pollard, J.K., Sussman, E.D. and Sterns, M. 1990. Shipboard Crew Fatigue, Safety and Reduced Manning. US Department of Transportation, MAT011/WOO29, November 1990.

Psarros, G., Skjong, R., \& Eide, M. S. 2010. Under-reporting of maritime accidents. Accident Analysis \& Prevention, 42(2), pp. 619-625.

Richards, J., 2008. The many approaches to organisational misbehaviour: A review, map and research agenda. Employee Relations, 30(6), pp.653-678.

Roberts, S.E., Nielsen, D., Kotłowski, A. and Jaremin, B., 2014. Fatal accidents and injuries among merchant seafarers worldwide. Occupational medicine, 64(4), pp.259-266.

Sampson, H., 2013. International seafarers and transnationalism in the twenty-first century. Manchester University Press, Manchester.

Sampson, H., Turgo, N., Acejo, I., Ellis, N. and Tang, L., 2019. 'Between a Rock and a Hard Place': The Implications of Lost Autonomy and Trust for Professionals at Sea. Work, Employment and Society, 33(4), pp.648-665.

Sewell, G., \& Wilkinson, B. 1992. Someone to watch over me': surveillance, discipline and the just-in-time labour process. Sociology, 26(2), 271-289.

Taylor, F.W., 1947. The principles of scientific management, Scientific Management. New York \& London: Harpers \& Brothers, $c$.

Underhill, E. and Quinlan, M., 2011. How precarious employment affects health and safety at work: the case of temporary agency workers. Relations Industrielles/Industrial Relations, 66(3), pp.397-421.

Vidan, P., Dlabač, T., and Jerković, G. 2015. Familiarisation Aboard Ships of Croatian and Montenegrin Officers. Transactions on Maritime Science, 4(02): 113-118.

Wadsworth, E.J., Allen, P.H., McNamara, R.L. and Smith, A.P., 2008. Fatigue and health in a seafaring population. Occupational medicine, 58(3), pp.198-204.

Walters, D., 1996. Trade unions and the training of health and safety representatives in Europe. Employee Relations, 18(6), pp.50-68. 
Walters, D., and Bailey, N., 2013. Lives in Peril: Profit or Safety in the Global Maritime Industry? Springer.

Walters D., and Wadsworth E., 2020. Arrangements for workers' safety and health in container terminals: Corporate core values and concrete practice. Economic and Industrial Democracy, doi.org/10.1177/0143831X19893767.

Webb, M., and Palmer, G. 1998. Evading surveillance and making time: an ethnographic view of the Japanese factory floor in Britain. British Journal of Industrial Relations, 36(4), 611-627.

Winchester, N. and Alderton, T., 2003. Flag state audit 2003. Seafarers International Research Centre (SIRC), Cardiff University.

Winchester, N., Sampson, H., and Shelly, T. 2006. An analysis of crewing levels: findings from the SIRC Global Labour Market Survey.

Wu, B. and Winchester, N., 2005. Crew study of seafarers: a methodological approach to the global labour market for seafarers. Marine Policy, 29(4), pp.323-330.

\footnotetext{
' White flags are classified as quality flags, grey flags are classified as between quality and medium risk and black flags are classified as between medium risk and high risk. For further details see Paris MOU (2017)

ii Working a schedule of 6 hours on/ 6 hours off
} 


\section{Appendix I: Table of Shipboard Working Arrangements}

\begin{tabular}{|c|c|c|c|c|c|c|c|}
\hline \multirow[t]{3}{*}{ Position/rank } & \multicolumn{3}{|c|}{ Scheduled daily work hours at sea } & \multicolumn{2}{|c|}{ Scheduled daily work hours in port } & \multicolumn{2}{|c|}{$\begin{array}{l}\text { Total daily rest } \\
\text { hours }\end{array}$} \\
\hline & Watch & reeping & $\begin{array}{c}\text { Non-watchkeeping } \\
\text { duties }\end{array}$ & $\begin{array}{l}\text { Watchkeeping (from } \\
\text { - to) }\end{array}$ & $\begin{array}{l}\text { Non-watchkeeping } \\
\text { duties (from - to) }\end{array}$ & $\begin{array}{l}\text { At } \\
\text { sea }\end{array}$ & $\begin{array}{l}\text { In } \\
\text { port }\end{array}$ \\
\hline & (from-to) & (from-to) & (from-to) & & & & \\
\hline Captain & & & $\begin{array}{l}08.00-12.00, \\
13.00-17.00\end{array}$ & & $\begin{array}{c}08.00-12.00,13.00- \\
17.00\end{array}$ & 16 & 16 \\
\hline Chief Officer & $\begin{array}{l}04.00- \\
08.00\end{array}$ & $\begin{array}{l}16.00- \\
20.00\end{array}$ & $08.00-10.00$ & $04.00-08.00$ & $16.00-20.00$ & 14 & 14 \\
\hline Second Officer & $\begin{array}{l}00.00- \\
04.00\end{array}$ & $\begin{array}{l}12.00- \\
16.00\end{array}$ & $10.00-12.00$ & $\begin{array}{l}00.00-06.00 / 12.00- \\
18.00\end{array}$ & & 14 & 12 \\
\hline Third Officer & $\begin{array}{l}08.00- \\
12.00\end{array}$ & $\begin{array}{l}20.00- \\
24.00\end{array}$ & $13.00-15.00$ & $\begin{array}{l}06.00-12.00 / 18.00- \\
24.00\end{array}$ & & 14 & 12 \\
\hline Bosun & & & $\begin{array}{c}06.00-12.00,13.00 \\
-17.00\end{array}$ & & $06.00-18.00$ & 14 & 12 \\
\hline AB (Watchkeeper) & $\begin{array}{l}04.00- \\
08.00\end{array}$ & $\begin{array}{l}16.00- \\
20.00\end{array}$ & $08.00-10.00$ & $\begin{array}{l}00.00-06.00 / 12.00- \\
18.00\end{array}$ & & 14 & 12 \\
\hline $\mathrm{AB}$ (Watchkeeper) & $\begin{array}{l}00.00- \\
04.00\end{array}$ & $\begin{array}{l}12.00- \\
16.00\end{array}$ & $10.00-12.00$ & $\begin{array}{l}06.00-12.00 / 18.00- \\
24.00\end{array}$ & & 14 & 12 \\
\hline AB (Watchkeeper) & $\begin{array}{l}08.00- \\
12.00\end{array}$ & $\begin{array}{l}20.00- \\
24.00\end{array}$ & $13.00-15.00$ & $\begin{array}{l}00.00-06.00 / 12.00- \\
18.00\end{array}$ & & 14 & 12 \\
\hline AB (Day man) & & & $\begin{array}{l}06.00-12.00, \\
13.00-17.00\end{array}$ & $\begin{array}{l}06.00-12.00 / 18.00- \\
24.00\end{array}$ & & 14 & 12 \\
\hline OS & & & $\begin{array}{l}06.00-12.00, \\
13.00-17.00\end{array}$ & & $\begin{array}{l}06.00-12.00 / 13.00- \\
17.00\end{array}$ & 14 & 14 \\
\hline Chief Engineer & & & $\begin{array}{c}08.00-12.00,13.00- \\
17.00\end{array}$ & & $\begin{array}{c}08.00-12.00,13.00- \\
17.00\end{array}$ & 16 & 16 \\
\hline Second Engineer & & & $\begin{array}{l}08.00-12.00, \\
13.00-17.00\end{array}$ & & $\begin{array}{c}08.00-12.00,13.00- \\
17.00\end{array}$ & 16 & 16 \\
\hline Third Engineer & & & $\begin{array}{l}08.00-12.00, \\
13.00-17.00\end{array}$ & & $\begin{array}{c}08.00-12.00,13.00- \\
17.00\end{array}$ & 16 & 16 \\
\hline Motorman & & & $\begin{array}{l}08.00-12.00, \\
13.00-17.00\end{array}$ & & $\begin{array}{c}08.00-12.00,13.00- \\
17.00\end{array}$ & 16 & 16 \\
\hline Cook & & & $\begin{array}{r}06.00-13.00, \\
15.00-18.00\end{array}$ & & $\begin{array}{l}06.00-13.00,15.00- \\
18.00\end{array}$ & 14 & 14 \\
\hline
\end{tabular}




\begin{tabular}{|l|l|l|l|l|l|l|}
\hline \multirow{2}{*}{ Mess man } & & & $06.00-13.00$, & & $06.00-13.00,15.00-$ & \\
\hline
\end{tabular}

0

3

(5)

8

0

